\title{
Welfarist and Imperial: The Contributions of Anticruelty Laws to Civilizational Discourse
}

\author{
Maneesha Deckha
}

The human-nonhuman binary exerts tremendous influence in West-
ern societies where social, cultural, and legal orders have taken shape
through a species divide that values humans above all other beings. Although the human-nonhuman distinction and anthropocentric value-system are formative to Western societies, it would be a mistake to read their effects in isolation. Human problematizations about nonhuman beings are rarely ever just about the nonhuman, but mediated by other circuits of difference. This intersectional claim that ideas of species difference and nonhumans are affected by other hierarchies of difference is relatively new to intersectionality theory, which has taken human lives as its focus in showcasing the interrelatedness of gendering, racializing, and other difference dynamics. ${ }^{1}$ Nevertheless, more and more scholars are attending to the connections between speciesism, racism, sexism, and other forms of oppression. ${ }^{2}$ For many, demonstrating these connections is a way to represent animal exploitation as a serious issue to an audience typically immersed in humanist epistemologies. Rather than merely argue, however - as prominent animal ethics theories have previously done ${ }^{3}$ - that speciesism is like racism and sexism, intersectional posthumanist theory goes farther to reveal how these logics of domination are intertwined. The intersectional claim about species brings animals and their experiences into the zone of ethical regard and justice within critical theoretical frameworks.

I seek to add to the strength of this intersectional claim by unpacking the racialized, religious, classed, and gendered dimensions of anticruelty legislation both in their genesis and in their current forms. By "anticruelty legislation" I am referring to statutes that either as a whole or through specific provisions prohibit certain uses and activities involving animals, violations of which constitute a criminal or regulatory offense, and/or incorporate a generic offense against the "unnecessary suffering" or "inhumane" treatment of animals (or words to similar effect). In the United States, all fifty states have these types 
of anticruelty statutes or provisions as part of their criminal law. ${ }^{4}$ Despite the variation in specific wording and content, two of the hallmark features of US anticruelty legislation (similar to their historical antecedents and international counterparts) are (1) the outlawing of animal neglect and abandonment and certain forms of animal fighting and baiting; and (2) a generic provision that makes unnecessary or otherwise unwarranted or inhumane suffering an offense. ${ }^{5}$ It is these elements of anticruelty legislation that come under close scrutiny here. To discuss US federal initiatives in this area, my reference to "anticruelty laws" also reaches beyond their traditional location in criminal law to include subject-area specific statutes at the federal level that seek to ensure "humane" standards and thus regulate animal suffering involved in a particular activity. ${ }^{6}$

My aim is to showcase how laws against animal cruelty create proximity in the social constructedness of various forms of difference. Specifically, laws directed at cruelty to animals have helped sustain a discourse of civilization that cuts across and animates hierarchical logics of race, religion, class, and gender. Such laws can be impugned for their imperial contributions. This analysis, then, underscores a different problem with anticruelty laws than what animal law scholars have emphasized. This more familiar critique, inspired by the influential work of the American law professor Gary Francione, stresses the inefficacy of these laws in preventing animal suffering, labeling them "welfarist" because of their mandate to regulate animal exploitation rather than prevent it. My argument seeks to add to the important work that Francione has done in pointing out the severe shortcomings of anticruelty laws by focusing here on the imperial underpinnings of these welfarist laws.

I begin by discussing the emergence of anticruelty statutes in the common law and their impact in the colonial project. Legislation targeting animal cruelty first emerged in the United States and England in the nineteenth century; similar statutes soon spread throughout the United States and the British Empire. Far from representing concerted action to uproot violence against animals, ${ }^{7}$ legislation instead reinforced civilizing missions with respect to both domestic and colonial populations through a legislative purpose that can be properly understood only by reference to race, religious, class, and gender dynamics. I then reveal how the civilizing purposes of anticruelty statutes continue to shape contemporary anticruelty jurisprudence. These laws are still used to domesticate populations marginalized by race, class, culture, and religion, and to signal civilizational superiority. ${ }^{8}$

In tracing the contributions of anticruelty laws to civilization discourses that have and still do stratify humans along multiple grounds, the analysis 
highlights the selective register by which these laws function, namely, effectively targeting minoritized practices and immunizing majoritarian ones. By minoritized practices I am referring to those uses and treatment of animals that are perceived to transgress dominant cultural norms; at times, such practices are represented as the deviant actions of aberrant individuals within the majoritarian society, and at other times they are attributed to ethnically, racially, religiously, or class-based subcultural groups within society.

In advancing this argument, my claim is not that civilizational thinking was the only rationale for these statutes or that genuine concern about animal suffering was absent from the motivations of legislators in voting on bills or amendments or of judges in interpreting these laws. Nor do I wish to discount the roles played by individual political personalities in the rise of anticruelty legislation in different common law jurisdictions and those members of the dominant cultural elite who went against majoritarian sentiment and advocated for better, more comprehensive protections. ${ }^{9}$ Instead, I wish to excavate the role anticruelty statutes played in civilizational thinking both in the metropole and in the colonies, and the residual impact of their early civilizational rationale in contemporary jurisprudence.

\section{The Genesis of Anticruelty Statutes}

Contemporary anticruelty statutes are a product of the Enlightenment and the contested ideas about difference and natural hierarchies that materialized in that formative era in Western political and cultural thought. Exploring the genesis of anticruelty legislation reveals the variety of social currents and individual personalities that played a part in enacting and amending these laws over almost two centuries in different continents and countries. One such social current-civilizational ideology steeped in power relations of class, gender, religion, and race-helped mobilize these statutes into being in the United Kingdom and settler societies. ${ }^{10}$ In particular, the literature indicates several factors that were critical to the instigation of anticruelty statutes. These related to changing societal attitudes about the role of domesticated animals and civilizing missions centered on discourses of class, race, and religion. Before discussing the influence of these factors more fully, it is useful to recall the legal context in which the statutes arose and their legal effects.

\section{Legal Instantiations}

Prior to the enactment of anticruelty legislation, common law (i.e., judge-made law as opposed to statutory law) did not provide any specific protections against 
cruelty toward animals. ${ }^{11}$ The only legal actions available before legislation appeared in this area were actions based on infringing another's property rights or relating to other charges such as nuisance, mischief, or disturbing the public peace. ${ }^{12}$ As David Favre and Vivien Tsang comment in their review of the rise of these statutes in the United States during the nineteenth century, the law permitted men to treat their animals, along with their wives and children, as they wished; ${ }^{13}$ property rights and attendant ideas about the importance of the sanctity and privacy of the home for male property owners precluded state intrusion either through legal regulation or through judicial attention. ${ }^{14}$

The legal concept of cruelty toward animals crystallized through legislation. The first major anticruelty statute in English jurisprudence was Martin's Act in the UK in 1822; it was limited to animals considered "cattle" (predominantly cows and other major farm animals) and covered other domestic animals only in $1835 .{ }^{15}$ In the United States, the first state anticruelty statute appeared a year earlier in Maine in 1821, but it is the New York law enacted in 1828 that is typical of US statutes enacted during this part of the nineteenth century. ${ }^{16}$ As Favre and Tsang point out, like many of its counterparts, the New York law contained two divergent clauses: prohibiting interference with one's animals through acts that "kill, maim or wound," but also enjoining anyone, including the owner, from "cruelly" beating or torturing these animals. ${ }^{17}$ The first clause replicated the preexisting "malicious mischief" laws directed at stopping third parties from damaging owners' interests in their property; by incorporating the second type of clause, anticruelty statutes were regarded as different from the earlier "malicious mischief" provisions represented by the former clause. ${ }^{18}$ Thus, on their face, anticruelty laws began to shift from the singular preoccupation with third-party interference with ownership rights in animals by including provisions against cruelty regardless of whether the animal at issue was owned by the accused or by someone else (wild animals, which were excluded from malicious mischief laws, continued to be excluded from anticruelty statutes). ${ }^{19}$

Anticruelty laws, however, were still primarily directed at "cattle," a category that included cows, sheep, and other economically significant farm animals. ${ }^{20}$ Various other states followed the 1828 New York law by enacting similarly worded legislation over the next thirty years, also restricting their application to this select group of animals. ${ }^{21}$ With their focus on cattle, these early statutes prioritized economically significant animals and were meant to target the behavior of third parties that would diminish the value of a major source of owners' assets. ${ }^{22}$ Even where these statutes made it an offense for owners to beat and torture their own animals, the rationale for these types of provisions was to express "concern ... for the moral state of the human actor, rather than 
the suffering of the non-human animals." ${ }^{23}$ The offense was understood as an assault on public morals and not a direct harm to the animal. ${ }^{24}$

Anticruelty statutes continued to apply only to animals that held economic value for almost the next forty years in the United States. ${ }^{25}$ It was only in 1867 , as part of a set of substantive amendments, ${ }^{26}$ that the scope of the New York law was broadened to include other domestic animals. ${ }^{27}$ Favre and Tsang observe that the 1867 legislation was a milestone for animals, as its purpose was to address animal suffering rather than protect the value of commercially coveted animals. ${ }^{28}$ Yet it is critical to note that these statutes were still motivated by anthropocentric interests (to elevate humans and public morals) ${ }^{29}$ and contained offense parameters that made it difficult to prosecute offenses. ${ }^{30}$ Further, when the underlying enforcement and interpretation of these latter statutes are probed, the property priorities become apparent. ${ }^{31}$ As Francione shows in his generative study of American case law in this field, when judges came to interpret the legislation, they typically inquired into the necessity of the animal suffering to determine the presence of "cruelty." In the calculation of what is "necessary" suffering and thus not "cruel," the property and other culturally accepted interests of humans always outweighed the interests of animals to justify the suffering as "necessary." 32 Francione calls this structural aspect of anticruelty legislation "legal welfarism" 33 and identifies it as the reason that anticruelty statutes were so ineffective in protecting animals and, conversely, so reliable at securing anthropocentric interests. ${ }^{34}$

Although anticruelty statutes did not protect animals from the bulk of the routinized violence inflicted on them-a situation that continues today, given that these laws in the United States and elsewhere closely resemble their historical antecedent ${ }^{35}$ - they were effective in communicating norms about what constituted appropriate human behavior toward animals. As Francione concludes from his review of American anticruelty cases, "the vast majority of cases in which defendants are found to have violated anticruelty laws involve the neglect of domestic animals, rather than the commission of affirmative acts"; $; 6$ in these situations it is mostly farm animals and the "socially undesirable destruction of property" through neglect and abandonment that the law impugns. ${ }^{37}$ Where actual affirmative acts are at issue, it is only "socially undesirable" behavior seen to be "deviant" and unrelated to socially acceptable pursuits, traditions, and identities (most notably, the maximization of social wealth and economic efficiency) that triggers these statutes. ${ }^{38}$ Anticruelty laws do not affect customary practices that are part of the social fabric or part of accepted institutional use of animals. ${ }^{39}$ As Francione emphasizes at the close of his study, "Legal welfarism provides for a level of animal welfare-and only 
that level of welfare-that is consistent with the efficient exploitation of the animal given the particular use involved." ${ }^{40}$

I want to build on Francione's analysis of legal welfarism by exploring the discourses of difference embedded in the legal welfarist classifications of violent human behavior toward animals, between what is acceptable and what, in contrast, is not because the behavior transgresses public morals and undermines human character. In this section I uncover the influence that discourses of civilization exerted in advancing ideas about what were proper public morals in the British context.

\section{Human Character, Public Morals, and Civilization Standards}

Postcolonial feminist scholars have generated a rich literature on how certain perceived gendered practices were harnessed as evidence of the cultural backwardness of colonial groups and used to justify colonial legal interventions as part of the overall civilizing mission. ${ }^{41}$ Less examined as part of law's role in civilizing missions is the similar deployment of anticruelty legislation in the colonies and its related effects in the metropole. ${ }^{42}$

\section{Cultivating Civilized Tastes at "Home"-a New Attitude toward (Some) Animals}

A gradual shift in societal conceptualizations of the human-nonhuman animal relationship during the Enlightenment influenced the development of anticruelty sentiment, helping to set the stage for eventual legislation. This shift evolved through class, race, religion, and gender identifications that materialized amid urbanization. Upper-class Victorian society, and then, as wealth spread, middle-class constituencies, embraced romanticism and sentimentality-highly gendered and class-based concepts ${ }^{43}$ — with regard to animals they kept at home as companions. ${ }^{44}$ Even lower-class families began the practice of keeping animal companions for affection purposes ${ }^{45}$ resulting in unparalleled and unconventional proximity to animals by many in society. Corwin Kruse articulates how this overall societal shift in sensibilities affected the animal advocacy movement as follows: "Victorians no longer viewed animals as commodities or tools, but as companions and even members of the family. For many, animals became objects of sentimentality rather than [simply] utility." 46 Having animals in such close quarters provided the opportunity to relate to them as individuals, observe their personalities, and enable a questioning of the prevailing "dominant Christian" representation that animals were vastly different from humans and lacked the capacity to feel. ${ }^{47}$ 
Further, as Victorian society entrenched the gendered and classed division of society into public and private spheres, certain companion animals, like upper-class women, came to occupy a distinct leisurely role to denote appropriate class status. ${ }^{48}$ Indeed, the popularity of "ladies lap dogs" demonstrates the gendered associations animals conveyed that contributed to the domesticity of the home, ${ }^{49}$ a space idealized as "the refuge (for men) from work in all its negativity." Wo Women and children, but also animals, were critical to the construction of this refuge and the patriarchal "cult of domesticity" that prevailed within it. ${ }^{51}$ This new signification of space led to anthropomorphization and the glorification of companion animals, ${ }^{52}$ but also facilitated a partial reconceptualization of how humans ought to treat nonhuman animals in general.

At the same time as proximity to animals in the home prompted a rethinking of human-animal relations more broadly, imperialism and the need to maintain a "civilized" identity vis-à-vis colonized peoples provided a further incentive to target certain violent practices in the metropole toward animals as "cruel." Their condemnation and eventual prohibition could then bolster the claim to a more civilized and progressive "home" culture and nation. As Grace Moore notes, "While for Victorians the city was the epitome of civilization and progress, cruelty to animals had become a sign of the metropolis's savage underbelly and a dangerous reminder of the perils of backsliding." ${ }_{33}$

The twin civilizing rationales for anticruelty reform-to cultivate a civilized status vis-à-vis the countryside and the colony-worked in tandem to shield the animal-based, and very violent, practices associated with the upper classes from the ambit of reform. By targeting instead the practices associated with the lower classes at the domestic level, the superior "national" identity of England could be articulated vis-à-vis colonial societies without jeopardizing Victorian animal-based practices. ${ }^{54}$ As a result, the early anticruelty statutes targeted what were seen to be lower-class abuses in blood sports ${ }^{55}$ and industry, ${ }^{56}$ while sidelining other activities, such as foxhunting, associated with the upper classes. ${ }^{57}$ In part, this appears to be pragmatic, as some animal welfare organizations received their central funding and support from upper classes. ${ }^{58}$ Upper-class blood sports such as hunting, however, were also justified by nationalist gendered and imperial rhetoric suggesting that too much caring about animals threatened the "good old British fighting spirit" that defined cultivated British masculinity. ${ }^{59}$

The civilizing focus on lower-class abuses is also reflective of the Benthamite philosophical influence that criticized the suffering of animals but not their exploitation, ${ }^{60}$ as well as the evangelical teachings that stressed that a primary 
benefit of these statutes would be their ability to elevate human morals. ${ }^{61}$ Compassion toward animals, which centered on the utilitarian notion that killing is justifiable given the ends but "prolonged suffering" was not, conveyed a civilized, Christian sensibility. ${ }^{62}$ Exhibiting such kindness toward sentient animals confirmed one's middle-class status and Christian identity; through adopting this orientation the lower classes acquired a way of thinking and feeling that would counter not only cruelty to animals and humans but a range of social ills produced by urbanization to which they were thought to be prone. ${ }^{63}$ Anticruelty proponents at that time sought to popularize compassion toward animals to a resisting public through two religious rationales: first, that humans should be kind to animals over whom they have dominion, and this models the relationship that God has with humans; and second, that compassion is a virtue that should extend (albeit in hierarchical order) to all God's creations, and it is the duty of the British, at the apex of human civilization, to widen its circle of compassion (or "of inclusion"). ${ }^{64}$

As intimated above, the evangelical-based animal advocacy at this juncture operated in the context of a national urge to improve public morals in general that in turn led to intense philanthropic motivation for a variety of causes aimed at addressing moral vices associated with the poor. ${ }^{65}$ Civilizing and religious rationales used to promote animal reform efforts were also present in campaigns against child labor and for women's rights in the metropole, and connections between the subordination of such human groups and animals were drawn. ${ }^{66}$ These campaigns advanced in part by exploiting British fears that the British could not legitimately distinguish themselves from the foreign populations they were colonizing, and thereby justify their civilizing missions that turned, in part, on narratives about how poorly women and children were treated, if they themselves did not treat women and children better. ${ }^{67}$ Upperclass Victorians thus began to associate superiority along class and racial lines, at home and abroad, with the inability to tolerate certain forms of suffering, thereby providing a frame of reference into which animal suffering could enter and resonate. ${ }^{68}$ Education against animal cruelty during childhood was viewed as a productive way to cultivate kindness in general so that those seen as most inclined to cruelty-lower-class men-would learn self-discipline against all forms of depravity. ${ }^{69}$

We can see then how multiple social phenomena (urbanization and the rise in companion animal-keeping, the idealization of domesticity, Evangelical concerns about cultivating kindness and morality, political concerns to distinguish the metropole from the colonies) all prompted a broad rethinking of 
how humans should relate to animals. These class, gender, religious, and race discourses together contributed to an overarching sense of civilizational order central to which were ideas about the type of human-animal relations a properly civilized society should model in the metropole. This sense of how humans should behave toward animals pivoted on a double standard. Christianity, as a religious doctrine espousing human dominion over animals, and Victorian thinking, in its promotion of a highly class- and gender-conscious regime of morality, created a domestic animal anticruelty discourse with similar biases. Nationalist discourses of what was important to Britain's identity and what threatened its civilizing image were similarly selective.

Benthamite utilitarianism, as a social theory built on classist and colonial prejudices, was not sufficient as a secular theory to expose the contradictions above even when religious justifications started to fall out of favor in the latter part of the eighteenth century and the Victoria era came to its close. ${ }^{70}$ The colonial expansion that was occurring simultaneously instead ensured that the problematic multilayered discourse of species, race, class, gender, and religious differences reached new audiences.

\section{Advancing the Colonial Civilizing Mission-Animal Markers of Civilizational Superiority}

While the upper-class and refined middle-class scrutiny fell on lower-class practices at home, the attention of the nation overall extended abroad to instigate reform in the colonies. ${ }^{71}$ The civilizing impulse is particularly pronounced in the colonial context where class, race, gender, and Christian discourses shaped colonial law reform. ${ }^{72}$ Christianity was particularly significant as it linked evangelical zeal with empire. ${ }^{73}$ Brett Shadle's extensive analysis of how anticruelty discourse circulated in Kenya illustrates how these discourses worked together. ${ }^{74}$ Although bourgeois sentiments about what constituted barbarism and savagery in Kenya relied on several sources of "evidence," perceptions about animal cruelty were formative to consolidating colonial identity and justifying the civilizing mission overall. ${ }^{75}$ Interestingly, whereas the British used corporal violence to motivate Kenyans to change other perceived cultural practices deemed unacceptable, the campaign against animal cruelty in Kenya was unique in trying to cultivate empathy through educational materials. ${ }^{76}$ The corporal violence, of course, helped the overall colonial project of subjugation of colonized peoples. ${ }^{77}$ The appeal to Kenyans' empathy in relation to changing their behaviors toward animals, however, directly aligned with the mission to cultivate new morals of compassion and kindness in relation to animal suffer- 
ing as a mark of civilized thinking. ${ }^{78}$ Both methods of civilizing (masculinized violence and feminized empathy) indicate that the focus on animal cruelty was primarily about legitimating colonialism rather than addressing animal suffering in its multitude of forms. ${ }^{79}$

Pratik Chakrabarti illustrates a similar picture of the difference-laced dimensions of anticruelty statutes in British colonial India. Notably, he shows how the first Act for Prevention of Cruelty to Animals passed in 1869 centered on the distinction between the colonized and colonizer: "It was restricted to draft and sport animals used by Indians and did not refer to the use of animals in research or those used in British sports." ${ }^{80}$ Chakrabarti discusses how animal experimentation was seen as integral to the masculine virtue of the British contrasted with the animal-worshipping, vegetarian Indian. ${ }^{81}$ Although this is not a point that Chakrabarti makes himself, others have noted the British perception of Indian vegetarianism as proof of the effeminate nature of Hindu masculinity. ${ }^{82}$ We may thus understand that the colonial dichotomy represented by British support for animal experimentation, but disavowal of Indian animal practices, was even more pronounced in its gendered significations. Similar to how nationalist struggles and colonial agendas marshaled women's bodies discursively to advance their positions, Chakrabarti notes how animals became potent symbols of colonial and anticolonial forces: the British used attitudes toward animals as part of a rationale to justify colonial rule, while Hindu segments of the colonized mobilized resistance to British rule through organizing for cow protection. ${ }^{83}$ What both Shadle and Chakrabarti illustrate is how the discourses about anticruelty statutes in colonial contexts were imbricated in civilizing missions as opposed to primarily addressing animal suffering.

\section{Legislative Purposes Revealed}

The combination of race, religious, class, and gender thinking in informing the rise of anticruelty legislation at home and abroad is perhaps no more apparent than in the records of legislative debates surrounding anticruelty bills in Britain. An examination of these debates reveals how the main proponents of these bills in Parliament incorporated the notions of dominion and Christian ideals that were so critical to the social discourse about cruelty to animals and connected these to civilizing rationales. ${ }^{84}$ An examination of the landmark and passionate speech Lord Erskine gave introducing the first bill to the House of Lords in 1809 reveals the religious civilizing animus for the law behind his genuine concern about working animals and the ubiquitous daily suffering they could endure. It leaves no doubt about his invocation of dominant Christian ideology about 
the dominion granted to man over "the lower world" to persuade his peers, promoting the view that with this power comes a moral duty to treat animals kindly. Lord Erskine insists that the bill wholly corresponds to this Christian duty, ensuring that although there is nothing in the law that challenges man's ability to use animals, the moral trust inherent in this God-given right to use animals demands that humans treat them kindly, given their equal capacities to suffer. In fact, this benevolence will better secure man's dominion, the realization of which is the goal of "the whole moral system." 85

The speech also makes evident that while Lord Erskine believes all of British society can benefit from education about this moral duty of all men, the messaging is most directed to the "lower orders" in society. The explicit and unabashed attribution of animal cruelty to the lower classes by members of Parliament during the readings of animal cruelty bills is a feature of the legislative debates that continued for over a century after Lord Erskine's 1809 speech. ${ }^{86}$

In addition to this class bias, the legislative debates also reveal the imperial legislative intent behind the bills. We can apprehend the view that the enactment of domestic statutes would foster Britain's imperial ambitions in several passages from Lord Erskine's 1809 speech where he expresses the belief that outlawing animal cruelty will elevate moral sentiment, allow other nations to model "the highest state of refinement and civilization," ${ }^{87}$ cause humans to treat each other better, and thereby raise the prospects for global peace "under the dominion of enlightened man, the lord and governor of all." 88

As Chien-hui Li notes, "This hope of a universal acceptance of Christianity and mercy toward animals was to evolve into the familiar British pride of empire." ${ }^{\prime 9}$ This questionable pride still persists in former colonies of the British Empire. As the next section reveals, anticruelty statutes continue to be a repository of civilizational meaning for their domestic legal systems and societies and continue to demand no more than minimal behavioral modification through their textual scope and judicial interpretation.

\section{Contemporary Anticruelty Statutes - the Civilizing Mission Continues}

The common law as a whole was critical to the establishment of British nationalist identity and empire building. ${ }^{90}$ As the discussion above evinces, the specific laws addressing animal cruelty reinforced the overall imperial ideology about civilizational hierarchies as well as the need for moral elevation "at home" among certain lower-class populations. Although different in its precise contours given different historical and cultural contexts, the interrelation between 
anticruelty laws and civilizing mind-sets has not disappeared but circulates today in jurisdictions where anticruelty legislation continues to operate. We can see this in two main ways.

\section{Dominant Practices Immune}

First, anticruelty law continues to selectively target minoritized practices as "cruel" while immunizing the vast range of normalized acts of violence against animals. Most notably, anticruelty legislation does not engage the institutionalized and routinized violence against animals in the food and research industries. In fact, these sites are almost always excluded from the purview of any applicable statutes by explicit exclusions. American legislation is illustrative. ${ }^{91}$ Federal law ensuring "humane" treatment in industrial agriculture does not address how animals are raised. ${ }^{92}$ Even then the standards are minimal, and the legislation specifically excludes chicken from its ambit. ${ }^{93}$ Of the ten billion animals slaughtered for human consumption in the United States annually, chickens and other poultry account for 92 percent of that body count. ${ }^{94} \mathrm{We}$ find the same kind of exclusion at the federal level in the realm of research. The Animal Welfare Act, ${ }^{95}$ a statute providing for minimal standards for the treatment of animals in research laboratories, excludes rats, mice, and birds ${ }^{96}$ which together account for 95 percent of all animals used in research. ${ }^{97}$ The statutes are already weak in substance, and the explicit exclusions render them almost impotent in their power to protect animals.

Where explicit exclusions do not exist, implicit exclusions deliver the same effect. Judges generate these implicit exclusions through their interpretations of the legislation, concluding that they are not meant to impugn socially acceptable institutional practices. ${ }^{98}$ As noted above, most often, it is the individual animal abuser whose aberrant actions (torturing cats, beating dogs) are targeted or individual owners who do not maintain adequate shelter, food, or veterinary care for their animals through gross neglect (horses found starving, hoarding of cats, exposing animals to extreme temperatures, etc.). ${ }^{99}$ Industrial practices and dominant cultural and economic uses of animals are largely immune, irrespective of the level of violence against animals. ${ }^{100}$

Francione has documented this differentiation in the enforcement of state anticruelty laws. ${ }^{101}$ A sampling of some of the legislation illustrates Francione's argument. Returning to New York, a jurisdiction whose original anticruelty statute was generative for so many other states, we see that its current anticruelty statute states that "torture" or "cruelty" includes every act, omission, or neglect, whereby unjustifiable physical pain, suffering, or death is caused 
or permitted. ${ }^{102}$ The New York law states, among other offenses, that anyone who "unjustifiably injures, maims, mutilates or kills any animal, whether wild or tame, and whether belonging to himself or to another," commits a misdemeanor. ${ }^{103}$ While the contemporary law includes wild animals in its purview, it still relies on the familiar trope of associating "cruelty/torture" only with suffering that is "unjustifiable." Without explicit statutory guidance for defining what is or is not "unjustifiable," judges may easily inscribe the term with anthropocentric meaning. What is more, the statute exempts "any properly conducted scientific tests, experiments or investigations, involving the use of living animals, performed or conducted in laboratories or institutions, which are approved for these purposes by the state commissioner of health," 104 making it clear that such use of animals is clearly justifiable.

New York also has a separate offense for "aggravated cruelty." The provision states:

A person is guilty of aggravated cruelty to animals when, with no justifiable purpose, he or she intentionally kills or intentionally causes serious physical injury to a companion animal with aggravated cruelty. For purposes of this section, "aggravated cruelty" shall mean conduct which:

(i) is intended to cause extreme physical pain; or

(ii) is done or carried out in an especially depraved or sadistic manner. ${ }^{105}$

Again, the concept of unjustifiable is used to qualify what will count as "aggravated cruelty" even where, as per subsection (ii), the conduct is "carried out in an especially depraved or sadistic manner." Recall that acts determined sadistic are one of the few types of acts that trigger anticruelty convictions. The New York law, then, is an example of current anticruelty legislation that condemns socially aberrant behavior, but claws back even this minimal scope of protection to allow a person to avoid the application of the statute if the act has a "justifiable purpose." Again, the assessment of what is or is not "justifiable" will turn on interpretation, and it is at this interpretive moment that the wider social and cultural context will apply to construe a legislative meaning that accords with community norms. ${ }^{106}$ Moreover, the offense of aggravated cruelty is also narrowed by explicit exemptions. Paragraph two of the provision states that nothing in the section is meant to interfere with lawful hunting, trapping, fishing, research, and other human uses. ${ }^{107}$

The highly qualified and exempting structure of the New York law is not an anomaly. One of Francione's central points in Animals, Property, and the Law is the similarity to each other of anticruelty laws in this regard. ${ }^{108}$ The numerous 
exemptions in anticruelty statutes excluding institutional and normalized uses of animals "are not exceptional, but, rather, are the rule when dealing with commodified animals." 109

\section{The Racialized and Religious Underpinnings of Contemporary Cruelty Standards}

Glen Elder, Jennifer Wolch, and Jody Emel have built on Francione's legal welfarist analysis by noting the racialized religious nature of practices that prompt anticruelty concern in communities. ${ }^{110}$ An exemplar of this pattern is the municipal ordinances that gave rise to the US Supreme Court case of Church of Lukumi Babalu Aye v. City of Hialeah, ${ }^{111}$ which the city of Hialeah, Florida, passed to prevent the opening of a Santeria church and related organizations. ${ }^{112}$ The planned complex and attendant activities would have involved the ritual slaughter of animals, a practice that the Santeria petitioners claimed was integral to their religion. ${ }^{113}$ Soon after the plans for the opening of the church were announced, the city held a meeting at which it passed Resolution 87-66 affirming its wish to prohibit religious practices that were "inconsistent with public morals, peace or safety." ${ }^{114}$ Critical to the further legislative action being contemplated was the prohibition on the ritual slaughter of animals not raised specifically for food. ${ }^{115}$

Knowing that, as a matter of constitutional law, the municipality could not pass any laws that were in conflict with state laws, the city sought legal advice from Florida's attorney general as to whether its intended ban on animal sacrifice would violate the state's anticruelty statute, which banned "unnecessary" suffering. ${ }^{116}$ As the court describes, the ensuing legal opinion from Florida concluded that the "ritual sacrifice of animals for purposes other than food consumption' was not a 'necessary' killing and so was prohibited." 117 As the court notes further, "The attorney general appeared to define 'unnecessary' as 'done without any useful motive, in a spirit of wanton cruelty or for the mere pleasure of destruction without being in any sense beneficial or useful to the person killing the animal."' 118 Having received state clearance for an animal cruelty-related ordinance, the city passed a series of ordinances—one of which specifically incorporated the Florida anticruelty law ${ }^{119}$ — that collectively outlawed animal sacrifice for ritual purposes. ${ }^{120}$ The church contested the ordinances on the basis of the First Amendment's free establishment clause but lost in the District Court and Court of Appeals. ${ }^{121}$ The church succeeded, however, at the US Supreme Court, which ruled that the ordinances violated the free exercise of religion and was not justified by a compelling government interest. ${ }^{122}$ 
The Supreme Court, to its credit, recognized the arbitrariness of the municipal ordinances in their collective prohibition of ritual slaughter where animals are not deliberately raised for food purposes (thus excluding kosher slaughter, licensed killing establishments, as well as any unlicensed killing of animals for food consumption). In a rare instance of judicial recognition of the discretion incorporated into an anticruelty statute and the discriminatory effects it can lead to, the Court writes:

The problem ... is the interpretation given to the ordinance by (the City) and the Florida attorney general. Killings for religious reasons are deemed unnecessary, whereas most other killings fall outside the prohibition. The city, on what seems to be a per se basis, deems hunting, slaughter of animals for food, eradication of insects and pests, and euthanasia as necessary. ... Respondent's application of the ordinance's test of necessity devalues religious reasons for killing by judging them to be of lesser import than nonreligious reasons. Thus, religious practice is being singled out for discriminatory treatment. (internal citations omitted) ${ }^{123}$

The Court underscores the distinction drawn between religious and secular reasons for killing. In comparing the other nontargeted killing that is still allowed in the city, including the acceptance of the killing of live rabbits in greyhound training, ${ }^{124}$ the Court's reasoning conveys a sense of the arbitrariness of the distinction and its underlying basis in dominant values. Indeed, the Court notes that the ordinances do not condemn "killings that are no more necessary or humane in almost all other circumstances." 125 The Court also discusses the actual record of public comments made at the initial city meeting where Resolution 87-66 was passed, which reveals repeated expressions of the view that Santeria practices must be banned, as they were in opposition to dominant Christianity and American values. ${ }^{126}$

Moreover, later in the judgment, when the Court discusses the "general applicability" of the ordinances-a second doctrinal step in the constitutional analysis mandated by the jurisprudence on the free exercise clause that examines whether the contested law applies equally to all religions - the Court highlights the underinclusiveness of the ordinances and the value-laden selectiveness of the laws. ${ }^{127}$

The city concedes that "neither the State of Florida nor the City has enacted a generally applicable ban on the killing of animals." It asserts, however, that animal sacrifice is "different." ... According to the city, it is "self-evident" that killing animals for food is "important"; the eradication of insects and pests is "obviously justified"; and the euthanasia of excess animals "makes sense." These ipse dixits do not explain why religion alone must bear the burden of the ordinances, when many of these secular killings fall within the city's interest in preventing the cruel treatment of animals. ${ }^{128}$ 
The passage is a rare and thus remarkable moment of judicial recognition of some of the double standards that attend human cultural attitudes about the acceptable use of animals that lay bare the city's reliance on a majoritarian pattern of unexplained "common sense" to legitimate the underinclusiveness of the ordinances. ${ }^{129}$

The Supreme Court's judgment in Church of Lukumi Babalu places anticruelty laws under close examination to reveal the value judgments that are inherent to determinations of cruelty. The judgment provides a clear example of how anticruelty laws are still heavily implicated in discourses of difference in the present day that legitimate majoritarian practices and target minoritized ones. Although the Supreme Court denounces the hypocrisy of the majoritarian purposes of the anticruelty ordinances, it would be a mistake to consider the decision as a welcome development for animals for this reason alone. Church of Lukumi Babalu turns on the religious infringement, that is, the human constitutional right violation; it does not turn on the protection of animal interests. ${ }^{130}$

\section{The Corporate Underpinnings of Contemporary Majoritarian Standards about "Cruelty"}

National Meat Association v. Harris (Attorney General of California) arose from the aftermath of an undercover video shot by the Humane Society of the United States in 2008. ${ }^{131}$ The video showed footage of animals at a California slaughterhouse who were unable to walk on the kill floor-referred to by the industry term of downer animals-being subjected to painful treatment to motivate them to stand up so that they could proceed to slaughter. ${ }^{132}$ The video's release prompted widespread concern; some of which was about animal welfare, but most of which was related to the health and safety of humans who consume injured and ill animals once they are rendered as "meat."133 The public outcry resulted in the largest animal flesh recall in United States history. ${ }^{134}$ California responded by passing California Penal Code 599 to prohibit the slaughter for consumption of nonambulatory animals, thereby creating a legal counter to industry practices to make nonambulatory animals move toward slaughter by any means possible to maximize profits.

Given this encroachment in revenue, the National Meat Association sued California, claiming that the state provisions were preempted by the federal statute on meat inspection that applied to slaughterhouses in California. ${ }^{135}$ Under the Federal Meat Inspection Act, ${ }^{136}$ animals must be classified into one of three different categories at the slaughterhouse prior to slaughter by the 
Federal Meat Inspection Act (FMIA) inspectors. ${ }^{137}$ If animals present with a condition on a list of condemned conditions, they must be slaughtered separately from their peers, and no part of the dead body may be used for human consumption. ${ }^{138}$ If animals are not suffering from one of the condemned conditions but are nonambulatory, they are classified as "US Suspect," and, if their condition does not improve, they are slaughtered separately. ${ }^{139}$ Here, however, the body awaits a further inspection to see what parts of the carcass are fit for human consumption.

The National Meat Association argued that the new California law contradicted the FMIA inasmuch as it treated the second category of animals differently: whereas federal law adopted a "wait and see" approach to nonambulatory animals, state law precluded their slaughter altogether. As the FMIA contained a clause that invalidated any state law that established a different regulatory regime than that provided for under the FMIA, ${ }^{140}$ the National Meat Association argued that California's prohibition on the slaughter of nonambulatory pigs for human consumption conflicted with the FMIA's specific preemption clause. ${ }^{141}$ The Supreme Court agreed, holding that the California regulatory scheme varied from the federal one. ${ }^{142}$

According to Justice Elena Kagan, who delivered the unanimous judgment for the Court, the FMIA "regulates the inspection, handling, and slaughter of livestock for human consumption." 143 Because it referentially incorporates the Humane Methods of Slaughter Act of 1958 (HMSA), the Court also accepts that it addresses the "humane handling of animals" 144 and that the mandate of the administrative agency charged with enforcing the FMIA, the Department of Agriculture's Food Safety and Inspection Service, includes "humane slaughter." ${ }^{45}$ In fortifying its reasoning that the FMIA is concerned with animal welfare, the Court also highlights a regulation under the FMIA itself that is related to "humane treatment" by directing that "slaughterhouse employees may not drag conscious, nonambulatory animals" and may move them only with "equipment suitable for such purposes." 146 The Court further notes "employees must place nonambulatory animals, as well as other sick and disabled livestock, in covered pens sufficient to protect the animals from 'adverse climatic conditions."' 147 These characterizations of both statutes and their regulations appear at the outset of the judgment and are reinforced later as well in response to the Humane Society's argument that the California provisions address anticruelty provisions, whereas the scheme of the FMIA does not. ${ }^{148}$

As David Cassuto argues in his critical appraisal of the judgment, the Court's reading of the HMSA (incorporated, as noted above, into the FMIA) as a guar- 
antor of "humane" treatment during slaughter is overdetermined. ${ }^{149}$ Cassuto cites several weaknesses of the HMSA in protecting animals. He notes that the statute, which was passed in 1906, was meant to regulate slaughterhouses to better ensure the health and safety of the workers, not the animals. ${ }^{150}$ When the text of the regulation is examined, one sees that workers are supposed to minimize injury "as little as possible." ${ }^{151}$ Such open-ended language, Cassuto notes, conveys immense discretion and little incentive for the workers to selfregulate in any meaningful way when facing pressures from superiors about minimizing the number of animals not sent to slaughter. ${ }^{152}$ Another HMSA provision indicates that all animals must be stunned before slaughter, but Cassuto notes that the intensely demanding pace of slaughter invariably entails that stunning will not be effective in all cases and that some animals will proceed through the process still conscious. ${ }^{153}$ In addition to noting the weaknesses of the regulations as they apply to the animals covered by the HMSA, Cassuto also reminds that the HMSA excludes 98 percent of animals sent to slaughter in the United States from its purview by explicitly excluding birds (and thus chickens) from its "protective" provisions. ${ }^{154}$

The Court overlooked all these important elements constituting the reality of slaughter and simply assumed that the FMIA addresses "humane" slaughter. ${ }^{155}$ This characterization of one of the statute's purposes was a critical move in favor of the National Meat Association as it enabled the Court to reach the conclusion that the California provisions violate the FMIA's preemption clause by addressing the same subject matter ("humane" slaughter) in a different way. The finding that California Penal Code 599 triggered the FMIA's preemption clause invalidated California's antislaughter regulatory scheme. ${ }^{156}$

The Harris judgment is a leading and recent example of judicial laxity in upholding meaningful protective standards for animals and of deference not only to industry arguments about the scope of humane laws but also to the corporate industry norms that anticruelty laws implicitly incorporate into definitions of acceptable and unacceptable animal treatment under these laws. Despite the Court's ability in Church of Lukumi Babalu to spot the hypocrisy in how states define "cruelty" and interpret the meaning of what is necessary and what is not under their anticruelty statutes, the Court is not able to translate its critical acumen there into a judgment that detects the marginal influence of animal welfare laws like HMSA and FMIA in protecting animals. The result in both Supreme Court cases is less protection for animals.

Moreover, having reviewed the Court's reasoning in Harris, we are now better able to appreciate a point made earlier: had the city of Hialeah ordinances banned all animal slaughter as "cruelty," and thus avoided a constitutional 
violation on religious grounds, the city would have been held to violate the FMIA because of its preemption clause. It would, of course, also likely have violated Florida's anticruelty law that permitted the killing of animals. Both state anticruelty laws and federal animal welfare law reflect dominant economic and cultural norms about how animals can be exploited with minimal regard to their welfare. What is telling with Harris is that here we have a state law from California that sought to do more; it sought to institute a new standard for the industry by banning the sale and thus consumption of all nonambulatory animals. Because it is in its own minority and subordinate to federal position in the overall landscape of the regulation of agricultural industry standards, the existing corporate industry standards that enjoy majoritarian status prevail.

Under this type of community value-determined "cruelty" framework, it is apparent how even the actions of institutional actors that try to circumvent any industry standards that may exist about animal treatment will appear as violations to the cultural and thus legal order. The contemporary operation of anticruelty laws, like their historical counterparts, continues to privilege practices accepted by the majority. Their protective radar falls, then, on minoritized practices within an industry or community. What comes across in the legal texts examined here is an appetite to use anticruelty statutes as an agent of civilization to outlaw practices a community deems immoral or "backward"; as Church of Lukumi Babalu illustrates, these targeted practices are those considered aberrant or deviant by cultural elites, often because of racialized and religious prejudices. Such "common sense" about what is civilized or not assumes that long-standing dominant cultural (including economic) practices at the slaughterhouse or elsewhere are beyond reproach. Both Church of Lukumi Babalu and Harris attest to the influence that powerful political and economic institutional actors exert in contributing to this largely unexamined common sense about what a civilized society will tolerate.

\section{Ongoing Relevance of Civilizational Discourse}

Although written decisions addressing anticruelty statutes are relatively limited-a phenomenon related to the rate at which offenses come to light and are prosecuted ${ }^{157}$ - even the relatively few cases that do exist exhibit civilizational discourse. Two appellate cases from the Canadian context demonstrate this. The first is the leading Canadian case on anticruelty. The second is a recent dissent that provides the most sophisticated and animal-friendly analysis to date of anticruelty statutes. In both, civilizational discourse is evident.

In $R v$. Ménard, ${ }^{158}$ which continues to be the leading Canadian case on the application of anticruelty legislation, the accused had a business capturing and 
killing cats and dogs who lived outdoors and over whom no humans claimed ownership. ${ }^{159}$ This was not the illegal part; ${ }^{160}$ what brought on the criminal charges of cruelty toward animals was the method he used. Ménard constructed a metal box where he would put the animal and to which he would hook up a motor that emitted carbon monoxide fumes that would kill the animals. ${ }^{161}$ Their deaths were slow and painful, as the gas burned their skin significantly. ${ }^{162}$ The court found that Ménard had "wilfully caused to animals pain, suffering or injuries"163 and that this pain and injury was not "inevitable taking into account the purpose sought and the means reasonably available."164

The case is notable and authoritative because of the extensive discussion provided by Justice Antonio Lamer (who was later to become the Chief Justice of Canada's Supreme Court) as to the purpose and application of animal welfare statutes. Justice Lamer's reasoning reveals the anthropocentric and speciesist biases of both the legislation and the judicial interpretation of cruelty toward animals. His judgment also explicitly evinces the class, race, and gender dimensions of the dominant property paradigm that guides the judicial protection of animals. This occurs in his discussion of "necessity" and in his related explanation of the place of animals in society, where it is transparent that the legal conceptualization of "necessity" is tethered to the court's appraisal of the value of animals in the larger cultural order.

After reciting the legal precedents for this case-cases that, not insignificantly, were decided in the late 1800s and early 1900s-Justice Lamer engages with the question of "necessity." He finds that it is the court's role to balance the animal's suffering against the necessity of the human endeavor that this suffering advances. ${ }^{165}$ This framework presupposes the supremacy of humans, and according to Justice Lamer, guards "against the danger of confusing compassion with sentimentality." ${ }^{166}$ Having oriented the decision on an anthropocentric axis, where human needs can be fulfilled despite the animal suffering that might result, Justice Lamer turns to justifying this with familiar civilizational language. He writes:

The animal is inferior to man and takes its place within a hierarchy of the animals, and above all is a part of nature with all its "racial and natural" selections. The animal is subordinate to nature and to man. ... This is why, in setting standards for the behaviour of men towards animals, we have taken into account our privileged position in nature. ${ }^{167}$

Justice Lamer's reasoning combines social Darwinist and anthropocentric thinking to marginalize not only animals but also humans along racial and gender lines. The term man is used unhesitatingly, and the quotations around 
"racial and natural" do not adequately acknowledge the racist ideology inherent to this harnessing of social Darwinist reasoning. Of course, counsel did not tender evidence about these theories; rather, Justice Lamer simply takes judicial notice of hierarchical ways of thinking about species, race, and gender differences as normalized cultural precepts for his legal analysis.

He goes on to fortify his points, all but explicitly acknowledging the colonial mentality from which he is working:

Thus men ... do not renounce the right given to them by their position as supreme creatures to put animals at their service to satisfy their needs, but impose on themselves a rule of civilization by which they renounce, condemn and repress all infliction of pain, suffering or injury on animals. ${ }^{168}$

Recall how the phenomenon of cruelty to animals was historically used to gauge civilizational status and justify the civilizing mission. Responsiveness to a particular type of animal suffering is again invoked in this more contemporary case as a marker of civilization and cultural superiority. And similar to how this animal-informed civilizational discourse circulated earlier, the court's reasoning here implicitly relies on dominant Christian religious understandings of man's natural dominion over animals. The current reasoning also resembles its historical counterpart by confirming human entitlement to exploit animals as resources and thus exhibits a double standard as to what counts as cruelty. Indeed, Justice Lamer even concedes a little later in the judgment that even though consuming animals as food is not necessary, it is acceptable because of species privilege. ${ }^{169}$

The Ménard decision was rendered in 1978, but its status as the highestlevel judicial pronouncement on the application of the federal anticruelty provisions means that its civilizational explanations about the purpose, scope, and application of anticruelty statutes continues to inform this area of law in Canada. Even a recent appellate and progressive animal-friendly decision finds the civilizational factor in Ménard a compelling enough point to affirm. In a dissenting decision that is also remarkable for the posthumanist reading it gives to anticruelty legislation - an interpretation of what the statute demands that exceeds the usual tepid welfarist interpretation these statutes receive-civilizational discourse is still present. Chief Justice Catherine Fraser of the Alberta Court of Appeal rendered a groundbreaking dissenting opinion in a 2011 case involving Lucy, a captive elephant kept at a government zoo in Edmonton, Alberta, who was suffering from social isolation and multiple chronic health problems. ${ }^{170}$ The decision is unprecedented in Canadian law because of its 
responsiveness to animal vulnerability in general, its sophisticated discussion of the field of animal law, and its willingness to push anticruelty law beyond its usual limited purview, particularly by virtue of its characterization of the Alberta government's failure to act to protect Lucy as a legal issue implicating the rule of law. ${ }^{171}$ No other appellate-level decision in Canada or the United States has delivered such an animal-friendly analysis of anticruelty law.

Despite these remarkable features, the decision incorporates Ménard's civilizational language and, by implication, its contested civilizational ideology. Indeed, Chief Justice Fraser stresses that anticruelty as a principle "continues to be the norm in Canada today" and, citing the passage from Ménard above, declares that it "is now so ingrained in our society that it is considered a rule of civilization [footnotes omitted]." 172 While she does not cite the Ménard passage reminiscent of social Darwinism in her decision, she nevertheless states later in the judgment that a "reasonable regard for vulnerable animals" is a trait "that a civilized society should show." 173 It may be too much to expect that the chief justice would have problematized civilizational rhetoric in her judgment, especially given all the other progressive insights of the analysis and the legal issue at stake. It would also be unfair to criticize her for relying on Ménard, given the importance of precedent to the common law method and her overall purpose in reasoning to an end point that animal issues should be taken seriously.

Yet it is still possible to observe that her incorporation of the civilizational language from Ménard attests to the ongoing resonance of civilizational hierarchy in anticruelty jurisprudence to situate one society as more advanced than others. Chief Justice Fraser's highlighting of legal doctrine that recognizes anticruelty laws as a "rule of civilization" to advance Lucy's interests rests on the premise that Canada belongs to the realm of civilized countries and intimates that other countries do not. A concern need not attach to every mention of civilizational language, of course. But when civilizational discourse rests on case law that exhibits clear civilizational ideology and forms part of an overarching jurisprudence in common law countries that gives explicit and implicit legal immunity to culturally dominant violence toward animals, the language confirms the contemporary participation of anticruelty laws in reinforcing multiple hierarchies of difference.

Anticruelty statutes, then, continue to be shaped by the selective distinctions drawn by their historical precursors. They still embody a double standard in that a practice will be classified as "cruel" not because of the amount of suffering involved but because of corporate and otherwise majoritarian views of 
the legitimacy of the practice. As in Victorian times when these statutes first started to gain traction, such majoritarian views are often heavily shaped by class, religious, cultural, and/or racialized norms of how "civilized" humans and societies should interact with animals. A second, less frequent, but nonetheless instructive way in which more recent anticruelty laws operate as civilizing agents occurs through the explicit civilizational language that appears in some notable anticruelty cases.

\section{Conclusion}

The primary critique that critical animal law scholars have lodged against anticruelty legislation involving assessments of what is "humane" treatment of animals is the latter's welfarist scope. These scholars have noted that such laws were not designed or interpreted to abolish routine human and institutional violence against animals or disturb the property status of animals. Rather, they were a legal attempt to elevate human morals; by promoting kind behavior toward animals, these laws aimed to inculcate better public morals in general. Anticruelty laws' welfarist scope is not their only limitation. These laws are also imperial to the extent that the behavior against animals that they typically target corresponds with problematic ideologies of civilizational status. Not only were the laws aimed at elevating public morals, but they were part of an agenda to secure the "civilized" identity of imperial powers and justify their power-laden civilizing missions vis-à-vis domestic and colonial populations.

Specifically, the onset of industrialization, religious revival, and the colonial enterprise contributed to new mind-sets about how "civilized" humans should interact with animals. In England, concerns about animal welfare gained in importance as part of the evangelical moral surveillance amid urbanization and the gendered romanticism and sentimentalism of the Victorian era. These sensibilities served to denote a higher-class status and dominant Christian values, and thus more civilized outlooks. These notions about civilizational status and animal-human relations were also taken abroad and were visible in colonial justifications for Christian civilizing missions. The anticruelty issue, much like the colonizer perception of how women were treated in the colonies, entrenched colonial ideas about racial and religious difference. Ideas about class, race, religion, and gender thus centrally contributed to the emergence and meaning of anticruelty legislation.

Anticruelty laws did not cease to be civilizing agents in the postcolonial period. Contemporary legislation and jurisprudence in the United States and 
Canada reveal the investment that anticruelty laws continue to make in civilizational discourse and ideologies. Current legislation is still effectively directed at the practices of minoritized individuals and communities, while the normalized institutional exploitation of animals continues unabated. Moreover, some cases still explicitly identify the civilizing influence of anticruelty statutes as one of their valuable purposes. For this reason, anticruelty laws merit criticism not only for their welfarist limitations but also for their imperial implications. Both grounds of criticism may be invoked to demonstrate the selective nature of anticruelty laws and the limits of what may typically be achieved under welfarist and imperial calibrations of "necessary" versus "unnecessary" suffering.

In excavating anticruelty law's imperial features, my intent is not to excuse the suffering visited on animals by minoritized communities or marginalized individuals. As Claire Jean Kim has noted, resistive responses to mainstream cultural surveillance through anticruelty initiatives have themselves "gone imperial" in complaining about Western cultural imperialism while continuing to assert their human superiority over animals. ${ }^{174}$ Nor should the present argument entail a singling out of law reform efforts dedicated to animal advocacy. After all, a similar critique about the civilizational origins and continuing marginalizing effects of human rights discourse and laws could also be made. ${ }^{175}$ Given the incrementalist and conservative method of the common law, its historical discursive and material participation in social stratifications of all kinds, ${ }^{176}$ and the continued dominance of various masculinist, Christian, and classist understandings that ground its most basic norms (such as the reasonable person, the concept of property and autonomy, etc.), ${ }^{177}$ almost every contemporary social justice-seeking law reform effort could be impugned as extending the imperial reach of problematic legal rhetoric. Indeed, the debate between critical legal scholars and feminist and critical race theorists about the desirability of rights discourse and the focus on rights in feminist and critical race advocacy pivots on this line of critique. ${ }^{178}$

The reading offered here of the imperialist and welfarist dimensions to anticruelty law can contribute instead to the debate in animal advocacy circles between those who believe in animal welfare efforts and those who do not as a productive means to end animal suffering. Currently, as stated at the outset, the criticism of animal welfare laws has centered on their selective nature. It is hoped that the additional insights here of how closely the selective nature of the law has aligned with imperial agendas and continues to produce social difference and reinforce existing power relations between humans and animals as well as among humans will further indicate the urgent need to develop a different legal framework to genuinely address and end animal suffering. At 


\author{
the very least, the critique of anticruelty laws as welfarist and imperial can \\ underscore the need to fundamentally shift the interpretation these statutes \\ typically receive so that routine and everyday dominant institutional practices \\ that harm animals will come under the ambit of what is "unnecessary/unjustifi- \\ able/inhumane" human treatment of animals.
}

\title{
Notes
}

The author would like to thank the Social Sciences and Humanities Research Council for generous research support as well as Jasreet Badyal and Michelle Stimac for excellent research assistance.

1. Maneesha Deckha, "Intersectionality and Posthumanist Visions of Equality," Wisconsin Journal of Law, Gender and Society 23.2 (2008): 249.

2. For examples of this intersectional line of critique, see Cathryn Bailey, "We Are What We Eat: Feminist Vegetarianism and the Reproduction of Racial Identity," Hypatia 22.2 (2007): 39; Maneesha Deckha, "Teaching Posthumanist Ethics in Law School: The Race, Culture, and Gender Dimensions of Student Residence," Animal Law 16.2 (2010): 287; Jody Emel, Chris Wilbert, and Jennifer Wolch, "Animal Geographies," Society and Animals 10.4 (2002): 407; Sarah Salih, "Filling up the Space between Mankind and Ape: Racism, Speciesism, and the Androphillic Ape," Ariel 38.1 (2007): 95.

3. See Peter Singer, Animal Liberation (New York: New York Review, 1975); and Tom Regan, The Case for Animal Rights (Berkeley: University of California Press, 1983).

4. For a detailed compendium that contains the general animal protection and related statutes, including penalties, for all the states, principal districts, and territories of the United States and Canada, see Animal Legal Defense Fund, "Animal Protection Laws of the United States of America and Canada," http://aldf.org/article.php?id=259.

5. Gary L. Francione, Animals, Property, and the Law (Philadelphia: Temple University Press, 1995).

6. The Animal Welfare Act 7 USC 54, section 2149 states a violation of any section of the act is an offense liable to a civil penalty of a maximum of $\$ 10,000$ for each violation, and each day during which a violation continues constitutes a separate offense. The Humane Methods of Slaughter Act 7 USC 1901-1907 in section 1902 states that any inhumane slaughtering or handling is in contravention of the public policy of the United States and provides descriptions of particular treatment that is in compliance with the act. Further, section 1907 (c) states that a violation of a regulation made by the secretary of agriculture providing for the humane treatment, handling, and disposition of nonambulatory livestock is subject to penalties provided under section 8313 of the Animal Health Protection Act 7 USC 8304, which contemplates both fines and imprisonment.

7. Most academics who challenge the place of animals in society contemplate the question of terminology. For example, in their introduction to a special issue of Feminist Theory on nonhuman feminisms, the editors Myra J. Hird and Celia Roberts write: "We need to ask from the outset what ontological fallout ensues from our delineating a nonhuman referent. In other words, do we attempt to define the human by what it is not, thereby instantiating the nonhuman within the human?" ("Feminism Theorises the Nonhuman," Feminist Theory 12.2 [2011]: 110). See also Gary L. Francione, "Reflections on Animals, Property, and the Law and Rain without Thunder," Law and Contemporary Problems 70 (2007): 9n1; Tom Regan, Animal Rights, Human Wrongs: An Introduction to Moral Philosophy (Oxford: Rowman and Littlefield, 2003), 1; and generally Harriet Ritvo, "On the Animal Turn," Daedalus 136.4 (2007): 118. In the present article I use the word animal to refer to nonhuman animals. This is problematic because it perpetuates the animal-human binary and ignores that humans are one species of animal. While recognizing the limitations of this term, I use it for simplicity.

8. My focus here is obviously on animals and is not meant to marginalize nonhuman actors that arguably receive even less attention and value under anthropocentric orders. My own view is that a proper correction to anthropocentrism will have to recuperate the subjectivities of all nonhuman living beings. 
For studies that focus on beings other than animals, see, e.g., Christopher D Stone, Should Trees Have Standing? (Los Altos, CA: W. Kaufmann, 1974); Paul Warren Taylor, Respect for Nature: A Theory of Environmental Ethics (Princeton, NJ: Princeton University Press, 1986); Donna Haraway, "A Manifesto for Cyborgs: Science, Technology, and Social Feminism in the 1980s," Australian Feminist Studies 2.4 (1987): 1; Kevin Warwick, "Cyborg Morals, Cyborg Values, Cyborg Ethics," Ethics and Information Technology 5 (2003): 131; Seth D. Baum, "Universalist Ethics in Extraterrestrial Encounter," Acta Astronautica 66.3-4 (2010): 617; Patrick Lin and Keith Abney, "Robot Ethics: Mapping the Issues for a Mechanized World," Artificial Intelligence 175.5-6 (2011): 942.

9. Kathryn Shevelow, For the Love of Animals: The Rise of the Animal Protection Movement (New York: Henry Holt, 2008). Shevelow gives many examples of both throughout her work. See, e.g., pages $10-11,49,177-81,182-91$.

10. It should be noted that I am refraining from using scare quotations around problematic terms such as civilizing missions. This is for ease of reading as opposed to accepting these notions.

11. Francione, Animals, Property and the Law, 121; Jerrold Tannenbaum, "Animals and the Law: Property, Cruelty, Rights," Social Research 62.3 (1995): 565.

12. This is not to say that the actions were easily available. For example, Tannenbaum notes how several states enacted malicious mischief acts that applied only if malicious intent was exhibited ("Animals and the Law," 551-64; see also David Favre and Vivien Tsang, "The Development of Anti-Cruelty Laws during the 1800s," Detroit College of Law Review 1 [1993]: 5). At common law, the definition of personal property, or chattels, was established largely on the grounds of economically useful domestic animals. Tannenbaum discusses how domesticated animals were the most valuable forms of personal property and, thus, how they were integral to the definition of chattels. Chattels could be the grounds for legal action, but remedies were limited to the value of the animal rather than the same animal. This was based on the notion that animals were fungible. See Tannenbaum, "Animals and the Law," 551-64.

13. Favre and Tsang, "Development of Anti-Cruelty Laws," 6.

14. See, e.g., John Tosh, A Man's Place: Masculinity and the Middle-Class Home in Victorian England (Bury St Edmunds: St Edmundsbury Press, 2007), 53-78; Corwin R. Kruse, "Gender, Views of Nature, and Support for Animal Rights," Society and Animals 7.3 (1999): 180-81.

15. Tannenbaum, "Animals and the Law," 565. The earliest known laws in the UK and United States were Ireland's Thomas Wenthworth's Act of 1635, which prohibited attaching ploughs to the tails of animals and pulling wool off sheep instead of clipping or shearing, and the Massachusetts Body of Liberties of 1641, which encouraged the humane treatment of animals. See Bruce A. Wagman and Matthew Liebman, A World View of Animal Law (Durham, NC: Carolina Academic Press, 2011), $149-50$.

16. Favre and Tsang, "Development of Anti-Cruelty Laws," 9. To be exact, the very first anticruelty law was created in 1641 in what would become Massachusetts (Tannenbaum, "Animals and the Law," 565). The 1828 law is cited in Tannenbaum, as New York Statutes, Pt. IV, Chapt I, Tit. VI. (1828). Favre and Tsang cite the revised law: N.Y. Rev Stat. tit. 6, s. 26 (1829) ("Development of Anti-Cruelty Laws," 9).

17. Favre and Tsang, "Development of Anti-Cruelty Laws," 9-10.

18. Francione, Animals, Property, and the Law, 124.

19. Favre and Tsang, "Development of Anti-Cruelty Laws," 8; Wagman and Liebman, World View, 148-52; Shevelow, For the Love of Animals, 4-11; Luis E. Chiesa, "Why Is It a Crime to Stomp on a Goldfish?-Harm, Victimhood, and the Structure of Anti-Cruelty Offenses," Mississippi Law Journal 78 (2008-2009): 8-9; Paula J. Frasso, "The Massachusetts Anti-Cruelty Statute: A Real Dog—a Proposal for a Red-draft of the Current Law," New England Law Review 35 (2000-2001): 1005; Charles E. Friend, "Animal Cruelty Laws: The Case for Reform," University of Richmond Law Review 8 (1973-1974): 201; Corwin R. Kruse, "Baby Steps: Minnesota Raises Certain Forms of Animal Cruelty to Felony Status," William Mitchell Law Review 28 (2001-2002): 1655; Joseph G. Sauder, "Enacting and Enforcing Felony Animal Cruelty Laws to Prevent Violence against Humans," Animal Law 6 (2000): 2-6; Brett L. Shadle, "Cruelty and Empathy, Animals and Race, in Colonial Kenya," Journal of Social History 45.4 (2012): 1099; Brian Bonhomme, "Russian Compassion: The Russian Society for the Protection of Animals-Founding and Contexts, 1865-75," Canadian Journal of History 45.2 (2010): 262-71; Diana Donald, "Beastly Sighs': The Treatment of Animals as a Moral 
Theme in Representations of London, c. 1820-1850," Art History 22.4 (1999): 514-16; Larry Falkin, "Taub v State: Are State Anti-Cruelty Statutes Sleeping Giants?," Pace Environmental Law Review 2 (1984-1985): 266; Pamela D. Frasch, "Addressing Animal Abuse: The Complementary Roles of Religion, Secular Ethics, and the Law," Society and Animals 8.3 (2000): 339; Chien-hui Li, "A Union of Christianity, Humanity, and Philanthropy: The Christian Tradition and the Prevention of Cruelty to Animals in Nineteenth-Century England," Society and Animals 8.3 (2000): 266; Susan Pearson, " "The Inalienable Rights of the Beast': Organized Animal Protection and the Language of Rights in America, 1865-1990," 15-16, http://web.law.columbia.edu/sites/default/files/microsites/law-culture/ files/2006-files/Pearson-Long.pdf; Mark J. Parmenter, "Does Iowa's Anti-Cruelty to Animals Statute Have Enough Bite?," Drake Law Review 51 (2002-2003): 820-22; Tannenbaum, "Animals and the Law," 565-78; Lesli Bisgould, Animals and the Law (Toronto, ON: Irwin Law, 2011), 58.

20. Favre and Tsang, "Development of Anti-Cruelty Laws," 7.

21. Ibid., 14 .

22. Ibid., 7.

23. Ibid., 11.

24. Francione, Animals, Property, and the Law, 146.

25. Favre and Tsang, "Development of Anti-Cruelty Laws," 14. Favre and Tsang proceed to note that there was ongoing confusion about whether the purposes of these laws were to protect property or prevent animal suffering (12).

26. Ibid., $15-16$.

27. Ibid.

28. Ibid., 18.

29. Francione, Animals, Property, and the Law, 123-24.

30. Favre and Tsang, "Development of Anti-Cruelty Laws," 14, 23.

31. Francione describes this change in philosophy as such: "The shift from malicious mischief statutes to anticruelty statutes was supposed to represent a shift from pure property protection to a concern for animals whether they were owned or not." Later on, however, he states that "although there was supposedly a dramatic difference between the theory of the anticruelty statutes and that of the malicious mischief statutes," they in reality "also focus primarily on property concerns" (Animals, Property, and the Law, 121-25, 143-45).

32. Ibid., 123, 125-26.

33. Ibid., 4 .

34. Ibid., 6, 18, 123.

35. Lesli Bisgould writes, referring to the development of the Canadian anticruelty Criminal Code provisions: "Their essence has changed very little. In the manner in which they seek to protect inherently conflicting interests-those of animals not to suffer, and those of people to cause such suffering" (Animals and the Law, 58).

36. Francione, Animals, Property, and the Law, 154.

37. Ibid., 155 .

38. Ibid., $145-46,153$.

39. Ibid., 147.

40. Ibid., 160 .

41. For a survey of such critiques, see Reina Lewis and Sara Mills, Feminist Postcolonial Theory: A Reader (London: Routledge, 2003). See also Sudhir Chandra, Enslaved Daughters: Colonialism, Law, and Women's Rights (New Delhi: Oxford University Press, 2008); and Anne McClintock, Aamir Mufti, and Ella Shohat, Dangerous Liaisons: Gender, Nation, and Postcolonial Perspectives (Minneapolis: University of Minnesota, 1997).

42. As Sally Merry notes, the exportation of law through colonialism affected both spaces ("From Law and Colonialism to Law and Globalization," Law and Social Inquiry 28.2 [2003]: 569).

43. See, e.g., Elizabeth A. Fay, A Feminist Introduction to Romanticism (Oxford: Blackwell, 1998), 1-22; and Anne K. Mellor, Romanticism and Gender (London: Routledge, 1993). Mellor shows how gendered our current understanding of romanticism is by proposing a paradigm shift through a focus on women writers. For an overview of her project, see Romanticism and Gender, 4-12. See also generally the works of Susan J. Wolfson, e.g., Romantic Interactions: Social Being and the Turns of Literary Action (Baltimore, MD: John Hopkins University Press, 2010) and Borderlines: The Shifting of Gender in British Romanticism (Stanford, CA: Stanford University Press, 2006). 
44. Favre and Tsang, "Development of Anti-Cruelty Laws," 2; Bonhomme, "Russian Compassion," 264; Donald, "Beastly Sighs," 514, Shevelow, For the Love of Animals, 60-61.

45. Shevelow, For the Love of Animals, 61.

46. Kruse, "Gender," 180.

47. Shevelow, For the Love of Animals, 74-75.

48. Animals characterized as "wild" or "food" were represented and understood as distinctly different from those animals that lived in the house and acted as "companion" to humans. See Martin A. Danahay: "Nature in Hoof and Paw: Domestic Animals and Violence in Victorian Art," in Victorian Animal Dreams: Representations of Animals in Victorian Literature and Culture, ed. Deborah Denenholz Morse and Martin A Danahay (Burlington, VT: Ashgate, 2007), 98. Danahay extrapolates the public-private divide to the domestic-foreign binary and has created an ingenious diagram that charts which species were considered as belonging in the home (and the nation) and outside (or in "other" nations). On the $\mathrm{x}$-axis, Danahay maps the species as they were understood from violent to most peaceful. For example, male dogs were seen as the most domestic of the violent animals, and monkeys, especially those in human clothing, were the most peaceful domestic animals. In contrast, tigers were both foreign and violent, and sloths were foreign but peaceful. This graph not only speaks to the qualities of animals that were most appreciated in a companion but also alludes to the impact of imperialism in the perception of animals (105-6).

49. Shevelow, For the Love of Animals, 64-65.

50. Tosh, Man's Place, 33.

51. Anne McClintock explores the "cult of domesticity" in Victorian cities, and the related "invention of the idea of the idle woman, the disavowal of women's work." See Anne McClintock, Imperial Leather: Race, Gender, Sexuality in the Colonial Contest (London: Routledge, 1995), 16. See also Lisa A. Keister and Darby E. Southgate, Inequality: A Contemporary Approach to Race, Class, and Gender (New York: Cambridge University Press, 2012), 228-30; and generally, although the term cult of true womanhood is used, Barbara Welter, “The Cult of True Womanhood: 1820-1860," American Quarterly 18.2 (1966): 151; and Claudia Nelson, Family Ties in Victorian England (Westport, CT: Praeger, 2007), 46.

52. Teresa Mangum provides an example of how this selective respect for certain animals manifested in Victorian society: the mourning of companion animals after their death. She writes, "Memorials marked the gap left by a distinct, valued animal personality. In all fairness, they also implicitly argued for the worth of animal life and even in some cases the hope for a reunion with the animal companion afterlife. The paradoxical problem with mourning was that memorialization idealized but also isolated the beloved pet as a being apart from the animal world of stray dogs, hunted animals, work animals, and 'food' animals" ("Animal Angst: Victorians Memorialize Their Pets," in Morse and Danahay, Victorian Animal Dreams, 31).

53. Grace Moore, "Beastly Criminals and Criminal Beasts: Stray Women and Stray Dogs in Oliver Twist," in Morse and Danahay, Victorian Animal Dreams, 204. See also Heather Schell's "Tiger Tales" where the author argues that the reason England's most ardent tiger hunters became vocal advocates of the protection of tigers in India was due to their identification with the animals, and identification that "entwined their sense of political power of the Indian people" ("Tiger Tales," in Morse and Danahay, Victorian Animal Dreams, 230; David Perkins, Romanticism and Animal Rights [Cambridge: University of Cambridge Press, 2003], 31).

54. Perkins writes that even at the time the hypocrisy of the beginning of the anticruelty movement, and more specifically the attempts to criminalize animal baiting, was criticized. He includes a paragraph from a journal of the day, in which one notable author writes: "The real thing that calls forth their sympathy, and harrows up their soul, is, to see a number of artizans, by a relaxation of their labour, baiting a bull or a bear, while a man with ten thousand a year may worry a hare, a stag, or a fox as he pleases!" (Romanticism and Animal Rights, 93, citing Lewis Gompertz in the Medusa, 1820). See also Harriet Ritvo, The Animal Estates: The English and Other Creatures in the Victorian Age (Cambridge, MA: Harvard University Press, 1987), 155-58. For an American Victorian perspective, see Diane L. Beers, For the Prevention of Cruelty: The History and Legacy of Animal Rights Activism in the United States (Athens: Ohio University Press, 2006), 51.

55. Perkins, Romanticism and Animal Rights, 93-95; Shevelow, For the Love of Animals, 49.

56. For example, Deborah Deneholz Morse argues that the novel Black Beauty was "intended for workingclass readers, as an anti-cruelty tract," exposing the life of a carthorse through the first-person narrative of the horse herself (“'The Mark of the Beast': Animals as Sites of Imperial Encounter from Wuther- 
ing Heights to Green Mansions," in Morse and Danahay, Victorian Animal Dreams, 187-89; Perkins, Romanticism and Animal Rights, 105).

57. Bonhomme, "Russian Compassion," 267; Donald, "Beastly Sighs,"” 514; Pearson, "Inalienable Rights," 22-23.

58. Beers, For the Prevention of Cruelty, 22.

59. Shevelow, For the Love of Animals, 51.

60. Parmenter, "Does Iowa's Anti-Cruelty to Animals Statute Have Enough Bite?," 820.

61. Favre and Tsang, "Development of Anti-Cruelty Laws," 23; Frasso, "Massachusetts Anti-Cruelty Statute," 1005; Shevelow, For the Love of Animals, 152.

62. Shadle, "Cruelty and Empathy," 1100.

63. Hilda Kean, cited in Kruse, "Baby Steps," 1655; Li, "Union of Christianity, Humanity, and Philanthropy," 267.

64. Li, "Union of Christianity, Humanity, and Philanthropy," 275-76.

65. Ibid., 266-67; Shevelow, For the Love of Animals, 159-60.

66. Perkins, Romanticism and Animal Rights, 58. "Even if it was not overly stated, an analogy to the lower classes could always be read into the discourse of animal rights. Animals also supplied a figure of speech for other socially subordinated human beings, for classes of persons who supposedly were more like animals, such as women, children, and subjected races in the expanding empire" (107). The focus on suffering within the anticruelty movement tethered it to other movements focused on cruelty toward children and women. Judith Fingard discusses how anticruelty movements focused on animals also extended their support to women and children ("The Prevention of Cruelty, Marriage Breakdown, and the Rights of Wives in Nova Scotia, 1880-1900," Acadiensis 22.2 [1993]: 85; Natan Sznaider, "Pain and Cruelty in Socio-Historical Perspective," International Journal of Politics, Culture, and Society 10.2 [1996]: 343; Bisgould, Animals and the Law, 97-98). Furthermore, the focus on suffering presents interesting links between the animal rights movement and antebellum abolitionist movements. The literature notes how both focused on the ability to suffer rather than possessing the capacity to reason as grounds for altering the legal system. For a discussion on the changing perspectives on human suffering that motivated the legal end to slavery in America, see Elizabeth B. Clark, "'The Sacred Rights of the Weak': Pain, Sympathy, and the Culture of Individual Rights in Antebellum America," Journal of American History 82.2 (1995): 473.

67. Rajeswari Sunder Rajan, Real and Imagined Women: Gender, Culture, and Postcolonialism (London: Routledge, 1993). Rajan shows how the legislative action by the East India's Company in India starting in 1829 (such as the abolition of sati) "served as the moral pretext for intervention and the major justification for colonial rule itself" (42). This moment of colonial history represents a dynamic that supported colonialism more generally: the perceived need for protection of women justified the oppression of all Indian people (42-48). See also Antoinette Burton, Burdens of History: British Feminists, Indian Women, and Imperial Culture, 1865-1915 (Chapel Hill: University of North Carolina Press, 1994), 7-8 where Burton articulates one of the themes of her book: to further their objective of achieving legal rights, British women engaged in racist discourse about Indian women.

68. Li, "Union of Christianity, Humanity, and Philanthropy," 271-72.

69. Shevelow, For the Love of Animals, 160.

70. Li, "Union of Christianity, Humanity, and Philanthropy," 277. For a discussion on the link between utilitarianism and colonialism, see Ratna Kapur, "Human Rights in the Twenty-First Century: Take a Walk on the Dark Side," Sydney Law Review 28.4 (2006): 665-87. Kapur highlights J. S. Mill's ideas on free speech, which he argued was an unfettered right for European men but not for the "native or 'colonial' subject ... based partly on the argument that this subject lacked the capacity to reason" (17). See also Piyel Haldar, "Utilitarianism and the Painful Orient," Social and Legal Studies 16.4 (2007): 573; and generally the essays included in Bart Schultz and Georgios Varouxakis, eds., Utilitarianism and Empire (Oxford: Lexington, 2005).

71. As Eve Darian-Smith notes, the fascination with the exotic other transcended class and gender stratifications at home: "Among all ranks and classes of English society there was a growing fascination with otherness and both its positive and negative qualities" (Religion, Race, Rights: Landmarks in the History of Modern Anglo-American Law [New York: Oxford University Press, 2010], 68).

72. For a discussion on the continued religious motivation behind the animal advocacy movement, see generally Lisa Kemmerer and Anthony J. Nocella II, eds., Call to Compassion: Religious Perspectives on Animals Advocacy (New York: Lantern Books, 2011). 
73. See, e.g., Jeffrey Cox, Imperial Fault Lines: Christianity and Colonial Power in India, 1818-1940 (Stanford, CA: Stanford University Press, 2002); Eliza F. Kent, Converting Women: Gender and Protestant Christianity in Colonial South India (New York: Oxford University Press, 2004); Penelope Carson, "An Imperial Dilemma: The Propagation of Christianity in Early Colonial India," Journal of Imperial and Commonwealth History 18.2 (1990): 169.

74. Shadle, "Cruelty and Empathy," 1098. He succinctly articulates the colonial logic as such: "Removing a young woman's clitoris held the tribe together; bludgeoning a harmless piglet to death contributed nothing to the world" (1098).

75. Ibid., 1101.

76. Ibid.

77. See, e.g., Paul Ocobock, "Spare the Rod, Spoil the Colony: Corporal Punishment, Colonial Violence, and Generational Authority in Kenya, 1987-1952," International Journal of African Historical Studies 45.1 (2012): 29.

78. Shadle, "Cruelty and Empathy," 1099.

79. See, e.g., Moira Ferguson, Animal Advocacy and Englishwomen, 1780-1900: Patriots, Nation, and Empire (Ann Arbor: University of Michigan, 1998) for a discussion on the gender dimensions of animal advocacy in England; Mary Ann Elston, "Women and Anti-vivisection in Victorian England, 1870-1900," in Vivisection in Historical Perspective, ed. Nicolaas A. Rupke (New York: Routledge, 1990), 259; and J. M. Jasper and D. Nelkin, cited in Kruse, "Gender," 180.

80. Pratik Chakrabarti, "Beasts of Burden: Animals and Laboratory Research in Colonial India," History of Science 48.2 (2010): 125 ("The Arya Samaj adopted the cow both as a symbol of Hindu compassion towards other life forms and as an icon of the unification of the Hindu community, as a response to colonial rule and in order to modernize Hinduism" [131]).

81. Ibid., 137-38.

82. See, e.g., Parama Roy, "Meat-Eating, Masculinity, and Renunciation in India: A Gandhian Grammar of Diet," Gender and History 14.1 (2002): 65; Jayanta Sengupta, "Nation on a Platter: The Culture and Politics of Food and Cuisine in Colonial Bengal," Modern Asian Studies 44.1 (2010): 86-90, 95-97; Tristan Stuart, The Bloodless Revolution: A Cultural History of Vegetarianism from 1600 to Modern Times (New York: Norton, 2006), 259.

83. Chakrabarti writes that through the adoption of the cow as a symbol of Hindu compassion toward other life forms, the Cow Protection movement was a "particular expression of Hindu nationalism" that labeled the British and Muslims as "outsiders' to the Hindu identity and morality as well as brutal because they consumed beef." On the other hand, the Indian Pasteur movement, whose followers desired the establishment of experimental institutes utilizing animals to treat rabies and other diseases, was "absorbed within Indian nationalism as a progressive and modernist movement" ("Beasts of Burden," 131-35).

84. Shevelow, For the Love of Animals, 9; Frasch, "Addressing Animal Abuse," 339-40; Li, "Union of Christianity, Humanity, and Philanthropy," 269.

85. A similar statement is made by another notable animal advocate of the time, Richard Martin, speaking to the House of Lords on Bear baiting and Other Cruel Sports: "though they could not be said to possess rights in the same degree as men, yet that being placed under the protection of man, they were entitled, so far as was consistent with the use which was given to map over the brute creation to be treated with kindness and humanity" (Parliamentary Debates, House of Commons, February 26, 1824, vol. 10 cc485-96).

86. See Parliamentary Debates, House of Commons, May 21, 1823, vol. 9 cc432-5; Parliamentary Debates, House of Commons, March 11, 1925, vol. 12 cc1002-13.

87. Parliamentary Debates, House of Lords, May 15, 1809, vol. 14 cc553-71.

88. Ibid.

89. Ibid.

90. Darian-Smith, Religion, Race, Rights, 62-63.

91. Other jurisdictions exhibit similar patterns. For example, the Ontario Society for the Prevention of Cruelty to Animals Act states, "Every person who owns or has custody or care of an animal shall comply with the prescribed standards of care with respect to every animal that the person owns or has custody of,"; however, this does not apply to "an activity carried on in accordance with reasonable and generally accepted practices of agricultural animal care, management or husbandry" (Ontario Society 
for the Prevention of Cruelty to Animals Act, RSO 1990, c O.36, s 11.1 [1], [2]). Other examples can be found in the following acts: BC Prevention of Cruelty to Animals Act, RSBC 1996, c 372, s 24.02; Animal Care Act, SM 1996, c 69, secs. 3(2), 4(1).

92. Humane Methods of Slaughter Act 7 USC 1901-1907.

93. Ibid.

94. Stephanie J. Engelsman, "World Leader-At What Price—a Look at Lagging American Animal Protection Laws," Pace Environmental Law Review 22 (2005): 335.

95. Animal Welfare Act 7 USC 54.

96. Transportation, Sale, and Handling of Certain Animals, 7 USC 54 at sec. 2132 (g)(1).

97. "Rats, Mice and Birds Excluded from Animal Welfare Act," American Psychology Association 33.7 (2002), www.apa.org/monitor/julaug02/rats.aspx.

98. See Bisgould, Animals and the Law, 74 .

99. Bisgould illustrates this argument - that only those cases deemed most horrific end in a guilty chargewith the details of a few examples (Animals and the Law, 81-87).

100. Ibid., 71-75.

101. Francione, Animals, Property and the Law.

102. N.Y. Agric. \& Mkts Law, Article 26, sec. 350. Hereafter cited as NYAGM.

103. Ibid.

104. Ibid., sec. 353.

105. Ibid.

106. Whether an act of cruelty and infliction of pain was justified or unjustified is "to be determined by the trier of facts based upon the moral standards of the community," and the justification "must be of the type necessary to preserve the safety or property or to overcome danger or injury." See People v Bunt, 462 NYS2d 142 (NY J Ct 1983) and People v Voelker, 658 NYS2d 180 (NY City Crim Ct 1997).

107. NYAGM, sec. 353.

108. Francione, Animals, Property and the Law, 134.

109. Thomas J. Catlaw and Thomas M. Holland, "Regarding the Animal: On Biopolitics and the Limits of Humanism in Public Administration," Administrative Theory and Praxis 34.1 (2012): 99.

110. Glen Elder, Jennifer R. Wolch, and Jody Emel, "Le Pratique Sauvage: Race, Place, and the HumanAnimal Divide," in Animal Geographies: Place, Politics, and Identity in the Nature-Culture Borderlands (London: Verso, 1998), 72.

111. (1992) 508 US 520, 113 S Ct 2217, 124 L Ed 2d 472.

112. Ibid., 526.

113. Ibid., 524.

114. Ibid., 526, citing Resolution 87-66.

115. Ibid., 526-27.

116. Ibid., 537. The Florida state provision at issue was section 828.12 .

117. Ibid., 536, citing Fla. Op. Atty. Gen. 87-56, Annual Report of the Atty. Gen. 146, 147, 149 (1988).

118. Church of Lukumi Babalu, para. 536, citing Fla. Op. Atty. Gen. 87-56, Annual Report of the Atty. Gen., 149n11.

119. Ibid., 527. In fact, the Supreme Court describes how the municipality sought a legal opinion from the state attorney general to ensure that any ordinance passed would not be in conflict with state law. The opinion that came back stating that since religious animal sacrifice did not fall within the state's definition of necessary it was illegal.

120. Ibid.

121. Church of Babalu Aye v City of Hialeah, 688 F Supp 1522, 1988 US Dist LEXIS 5675 (District court decision).

122. The free exercise clause and the freedom of establishment clause together make up the "religion clauses" of the First Amendment of United States. The first outlines the right to practice a religion without interference and the second prohibits the government from enacting laws that favor a religion. For a discussion on how these two clauses interact, and at times conflict, see, e.g., Jesse H. Choper, "The Religion Clauses of the First Amendment: Reconciling the Conflict," University of Pittsburgh Law Review 41 (1979): 673.

123. Church of Lukumi Babalu, 537-38.

124. Ibid., 493. Curiously, despite the clear text of the initial resolution that the city adopted stating that killing animals for ritual purposes is against public (read: dominant) morals and values, the Court does not make this connection clear. 
125. Ibid., 534 .

126. Ibid., 541-42. These comments are outlined on pages 541-42. The comments included in the decision are not subtle; the individuals, including elected government officials, who attended this meeting felt comfortable to explicitly employ their Christian beliefs to judge the legality of the practices of Santeria. One councilman said, "The Bible says we are allowed to sacrifice an animal for consumption, but for any other purposes, I don't believe that the Bible allows for that" (541). The chaplain for the city's police department said, "We need to be helping people and sharing with them the truth that is found in Jesus Christ" (542). Even the city attorney, who one would think would be more sensitive to the constitutional issues alive in this discussion, read the results of the Resolution as being that "this community will not tolerate religious practices which are abhorrent to its citizens" (542). The court also alludes to the charged atmosphere of the meeting, noting that people interrupted speakers with cheers (541).

127. The "general applicability" test is used by US courts to assess claims of infringement of the free exercise clause. Laws which affect religious expression must apply generally to all religions and not unduly burden only one. Finding that the local ordinances fail this test as they prohibit one specific form of religious expression, the Court states that "this precise evil is what the requirement of general applicability is designed to prevent" (545-46).

128. Ibid., 543.

129. The Court further comments that the city "has not explained why commercial operations that slaughter 'small numbers' of hogs and cattle do not implicate its professed desire to prevent cruelty to animals and preserve the public health. Although the city has classified Santeria sacrifice as slaughter, subjecting it to this ordinance, it does not regulate other killings for food in like manner" (ibid., 545).

130. Francione, Animals, Property and the Law, 160.

131. National Meat Association v Harris (Attorney General of California), 132 S Ct 965, $181 \mathrm{~L}$ Ed 2d 950, 80 USLW 4139.

132. "Rampant Animal Cruelty at California Slaughter Plant," Humane Society of the United States, January 30, 2008, www.humanesociety.org/news/news/2008/01/undercover_investigation_013008. html. Video available at the same URL.

133. David Cassuto, "Meat Animals, Humane Standards, and Other Legal Fictions," Law, Culture, and the Humanities (2012): 4-5, http://lch.sagepub.com/content/early/2012/07/16/1743872112450561.full. pdf + html. See, e.g., Matthew L. Wald, "Meat Packer Admits Slaughter of Sick Cows," March 13, 2008, New York Times, www.nytimes.com/2008/03/13/business/13meat.html?_r=1\&ref=westlandhallmark meatcompany. The CEO of the Hallmark/Westland Meat Company (which ran the slaughterhouses at issue in the case) Steve Mendell's comments are characterized as follows: "Mr. Mendell replied that after he had seen the first video, he concluded that 'it was a regulatory violation, for sure, it was inhumane treatment, for sure,' but that he did not believe it was a food safety issue until he saw the second video on Wednesday."

134. David Brown, "USDA Orders Largest Meat Recall in U.S. History," February 18, 2008, Washington Post.

135. California Penal Code, sec. 599-600.

136. Federal Meat Inspection Act, 21 USCS. The FMIA applies to California slaughterhouses because the act specifies that it applies where a state has not implemented an inspection system imposing the same standards as those under the act (FMIA, sec. 661(c)(1)). The application of the FMIA in this case is addressed in National Meat Association, 468.

137. 9 Code of Federal Regulations, sec. 309.

138. Ibid., sec. 309.3 .

139. Ibid., sec. 309.2.

140. This section states: "Requirements within the scope of this [Act] with respect to premises, facilities and operations of any establishment at which inspection is provided under . . this [Act] which are in addition to, or different than those made under this [Act] may not be imposed by any State" (ibid., 958-59, citing 21 U. S. C. sec. 678 [internal page references omitted]).

141. The treatment of the pigs in the slaughterhouses was the main issue, as the FMIA, like the California statute, prohibits nonambulatory cattle to be slaughtered for human food (FMIA, sec. 309.3 [e], referred to in National Meat Association, 973).

142. National Meat Association, 959. Its judgment reverses the decision of the Court of Appeals, which held that "states are free to decide which animals may be turned into meat" (963, citing 599 F. 3d, 1098, 1099). 
143. Ibid., 968.

144. Ibid.

145. Ibid.

146. Ibid., 958, citing sec. 313.2(d)(2) and sec. 313.2(d)(3).

147. Ibid., 958, citing sec. 313.2(d)(1) and sec. 313.1(c).

148. Ibid., 963-64.

149. Cassuto, "Meat Animals, Humane Standards, and Other Legal Fictions," 4.

150. Ibid. The FMIA has an interesting history; the creation of this act was motivated by the reaction to Upton Sinclair's novel The Jungle (Pasadena, CA: Upton Sinclair, 1906). Though fiction, the novel includes true accounts of the conditions in the meatpacking industry at the beginning of the twentieth century (Cassuto, "Meat Animals, Humane Standards, and Other Legal Fictions," 3). Sinclair's work is also cited in the National Meat Association, 968.

151. Cassuto, "Meat Animals, Humane Standards, and Other Legal Fictions," 3-4, citing 9 CFR, sec. 313.2 .

152. Ibid., 4.

153. Ibid. Cassuto provides a calculation that reveals how little time inspectors can spend on each animal: according to 2010 data, each inspector inspected 16,330 animals, and assuming they each worked full time and had no other duties, then each inspector saw 8 animals each hour (Cassuto, "Meat Animals, Humane Standards, and Other Legal Fictions," 5). Another figure that offers some perspective is provided by Timothy Pachirat: one animal is killed every twelve seconds in industrial slaughterhouses (Every Twelve Seconds [New Haven, CT: Yale University Press, 2011], 9).

154. Cassuto, "Meat Animals, Humane Standards, and Other Legal Fictions," 5.

155. Cassuto, "Meat Animals, Humane Standards, and Other Legal Fictions," 5-6, citing National Meat Association, pt. 2, para. 2.

156. Cassuto, "Meat Animals, Humane Standards, and Other Legal Fictions," 5-6.

157. Both the percentage of cases of cruelty toward animals that are prosecuted and the number of those prosecuted where the decision is reported are relatively low. In Canada, Bisgould states that "there is sometimes an apparent reluctance to attach criminal stigma by way of charges or conviction, as well as in the sentence imposed, when the victim of the crime is an animal" (Animals and the Law, 76). Bisgould goes on to show, in a very effective way, how few decisions involving animal cruelty are reported legally, by listing pages of cases that became public only when the media published the story (79-81). A similar situation exists in the United States and the United Kingdom. See Penny Conly Ellison, "Time to Give Anticruelty Laws Some Teeth—Bridging the Enforcement Gap," Journal of Animal Law and Ethics 3 (2009): 1; and Francione, "Reflections," 177n.

158. R v. Ménard, 1978 CarswellQue 25, 4 CR (3d) 333, 43 CCC (2d) 458.

159. Ibid., para. 55 .

160. Ibid., para. 58.

161. Ibid., para. 56.

162. Ibid., para. 57.

163. Ibid., para. 60.

164. Ibid.

165. Ibid., para. 47.

166. Ibid., para. 48. The desire to distance himself from animals, and to not empathize, is evident throughout Justice Lamer's judgment. The familiar refrain that emotion is irrelevant to legal discourse is used here to calibrate what is necessary and unnecessary suffering in accordance with mainstream practices.

167. Ibid., para. 49.

168. Ibid., para. 51.

169. Ibid., para. 465.

170. Reece v. Edmonton (City) [2011] AJ No 876; 2011 ABCA 238. Concerned about Lucy's health and well-being, and in light of the Humane Society's decision not to take legal action against the zoo, an application for a declaration that the city of Edmonton was in violation of the Animal Welfare Act was made by Tove Reece, PETA, and Zoocheck Canada. At the first trial the chambers judge struck the application on the grounds of abuse of process. The Alberta Court of Appeal upheld this ruling. For the majority, the only issue deemed important enough to guide the decision was the fact that "seeking a declaration takes the matter out of the hands of the Attorney General, and bypasses the penal sanctions contemplated by the Act" (ibid., para. 31). The appeal to the Supreme Court of Canada was dismissed (Reece v. Edmonton (City) [2011] SCCA No 447). 
171. Reece v. Edmonton, para. 158-60. Indeed, Chief Justice Fraser's comments about the rule of law have been subsequently cited for their importance. See Friends of the Canadian Wheat Board v. Canada 2011 FC 1432 CanLii; Cameron v. Canada (Indian Affairs and Northern Development), 2011 FC 570 CanLii. See also Maneesha Deckha, "Initiating a Non-Anthropocentric Jurisprudence: The Rule of Law and Animal Vulnerability under a Property Paradigm," Alberta Law Review (forthcoming).

172. Reece v. Edmonton, para. 56, citing Rv. Ménard, 465, leave den. [1978] 2 S.C.R. vii noting the passage, "Thus men ... impose on themselves a rule of civilization by which they renounce ... all infliction of pain, suffering or injury on animals which, while taking place in the pursuit of a legitimate purpose, is not justified by the choice of means employed" (ibid., 28n).

173. Reece v. Edmonton, para. 162.

174. Claire Jean Kim, "Multiculturalism Goes Imperial: Immigrants, Animals, and the Suppression of Moral Dialogue,” Du Bois Review: Social Science and Research on Race 4.1 (2007): 234-35.

175. See, e.g., Kapur, "Human Rights in the Twenty-First Century," 665.

176. See, e.g., Ian Haney-López, White by Law: The Legal Construction of Race (New York: New York University Press, 1996); Elizabeth Comack, ed., Locating Law: Race/Class/Gender/Sexuality Connections (Halifax: Fernwood, 2006); Beverly Moran and Stephanie M. Wildman, "Race and Wealth Disparity: The Role of Law and the Legal System," Fordham Urban Law Journal 34 (2007): 1219; and Omar Swartz, "Toward a Critique of Normative Justice: Human Rights and the Rule of Law," Socialism and Democracy 18.1 (2010): 185.

177. See Carol Smart, Feminism and the Power of the Law (London: Routledge, 1989); Jennifer Nedelsky, Law's Relations: A Relational Theory of Self, Autonomy, and Law (Oxford: Oxford University Press, 2011); and Mayo Moran, Rethinking the Reasonable Person: An Egalitarian Reconstruction of the Objective Standard (Oxford: Oxford University Press, 2003).

178. See Patricia Williams, Alchemy of Race and Rights: Diary of a Law Professor (Cambridge, MA: Harvard University Press, 1991); Sharon L. Roach Anleu, "Critiquing the Law: Themes and Dilemmas in Anglo-American Feminist Legal Theory," Journal of Law and Society 19.4 (1992): 423; Kimberlé Crenshaw et al., eds., Critical Race Theory: The Key Writings That Formed the Movement (New York: New Press, 1995). 